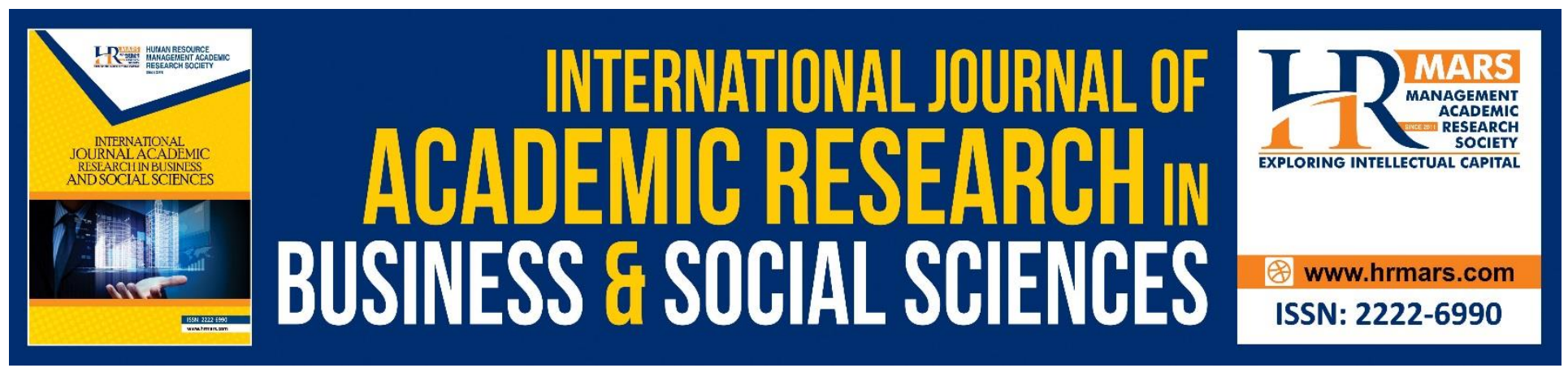

\title{
How the Government Quality can Help Boosting Infrastructure Investment and Economic Growth? A Closer Look at Indonesia's Practice
}

Tengku Citra Nisa Farza and Andri Zainal

To Link this Article: http://dx.doi.org/10.6007/IJARBSS/v8-i7/4396

DOI: $10.6007 /$ IJARBSS/v8-i7/4396

Received: 03 June 2018, Revised: 19 June 2018, Accepted: 29 June 2018

Published Online: 16 July 2018

In-Text Citation: (Farza \& Zainal, 2018)

To Cite this Article: Farza, T. C. N., \& Zainal, A. (2018). How the Government Quality can Help Boosting Infrastructure Investment and Economic Growth? A Closer Look at Indonesia's Practice. International Journal of Academic Research in Business and Social Sciences, 8(7), 542-553.

Copyright: (c) 2018 The Author(s)

Published by Human Resource Management Academic Research Society (www.hrmars.com)

This article is published under the Creative Commons Attribution (CC BY 4.0) license. Anyone may reproduce, distribute, translate and create derivative works of this article (for both commercial and non-commercial purposes), subject to full attribution to the original publication and authors. The full terms of this license may be seen at: http://creativecommons.org/licences/by/4.0/legalcode

Vol. 8, No. 7, July 2018, Pg. 542 - 553

Full Terms \& Conditions of access and use can be found at http://hrmars.com/index.php/pages/detail/publication-ethics 


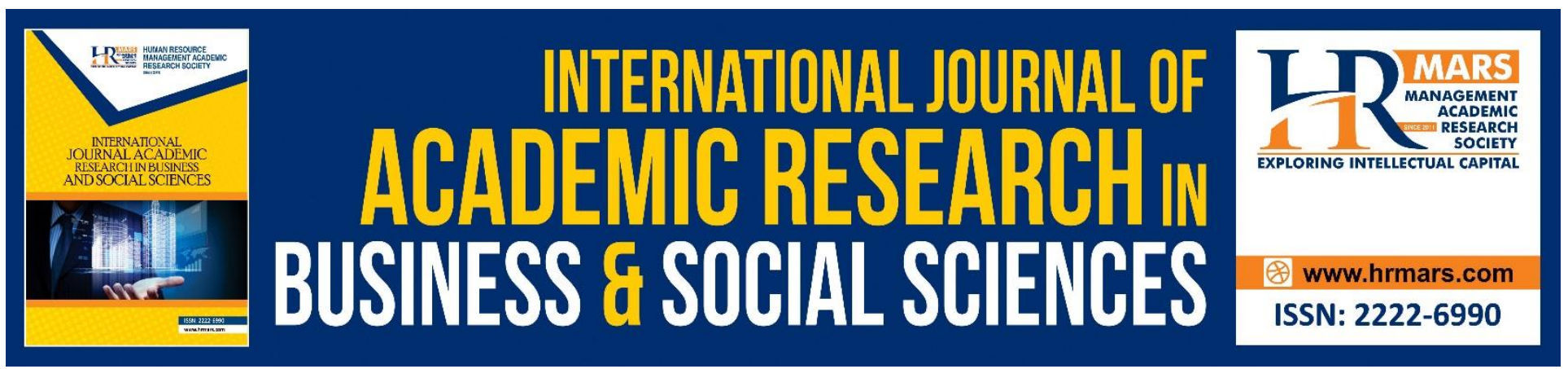

\title{
How the Government Quality can Help Boosting Infrastructure Investment and Economic Growth? A Closer Look at Indonesia's Practice
}

\author{
Tengku Citra Nisa Farza and Andri Zainal \\ Post Graduate of Economics, Universitas Negeri Medan, Indonesia \\ Corresponding author: t.citranisafarza@yahoo.com
}

\begin{abstract}
Extant literatures have suggested that the quality of infrastructure determines the successfulness of development occurred in a nation. It includes providing good transportation infrastructures e.g. roads, river, sea, air and railways that not only can facilitate people' movement abut also improve outcomes of business cycles connected through various transportation system. infrastructure, especially transportation infrastructure, which includes roads, rivers, sea, air and railways. In the case of the Indonesian economy with the classic issue of poor government governance, the weak role of transportation infrastructure in the national development tends to be in line with the low service quality and limited scope of services on the transportation-related sectors symbolizing ineffectiveness of existing transportation infrastructure to boost the economic growth of the nation. This paper aims to analyze the relationship among government quality, investment in transportation infrastructure and economic growth in Indonesia over $2000-2017$ period. The results of data analysis indicates that road length has a positive relationship with economic growth in the first 5 years and shows a negative relationship in the following year. The contribution of loading and unloading of domestic shipping goods on the economic growth only occurred in 2010. More interestingly, the quality of government reflected from unqualified opinion for the financial statements of Ministry of Transportation of Republic of Indonesia shows no impact to the infrastructure investment especially from foreign direct investment.
\end{abstract}

Keywords: Government Quality, Transport Infrastructure, Economic Growth, Indonesia

\section{Introduction}

Prior relevant studies about the positive correlations between infrastructure investments, particularly transportation infrastructure and economic growth of a country (See: Mohmand, Wang, \& Saeed, 2017; Sahoo, Dash, \& Nataraj, 2012; Yu, De Jong, Storm, \& Mi, 2012). Specifically, (Mohmand et al., 2017) discloses the funding characteristics of infrastructure investments between developing and developed countries by highlighting major differences in constraints on the credibility 
INTERNATIONAL JOURNAL OF ACADEMIC RESEARCH IN BUSINESS AND SOCIAL SCIENCES Vol. 8, No. 7, July 2018, E-ISSN: 2222-6990 @ 2018 HRMARS

of government agencies that affect the quantity and quality of investment in managed transport infrastructure between developing and developed countries. According to them, although a variety of partnership patterns of infrastructure investment funding has been offered by governments in developing countries such as public and private funding and funding by pure private sector but have not shown the expected performance where infrastructure investment including in transportation systems still tends to rely on financing from foreign loans and tax revenue. Thus, the pattern of investment in transportation infrastructure that continues to rely on foreign aid and tax revenues affects the relatively low growth of infrastructure in this sector and in the end it also affects the national economic growth.

Such conditions are also experienced by Indonesia. As one of the countries in the developing country group that is currently transitioning into a group of developing countries; is currently promoting massive transportation infrastructure development in various islands of the Republic of Indonesia. It is aimed to catch up with other developing countries, especially in its role as a major player in ASEAN Economic Community (AEC) and make Indonesia as one of the promising investment destinations to domestic and foreign investors through the improvement of significant and comprehensive transportation infrastructure throughout the region Indonesia. This is a major issue of concern to the Government of President Joko Widodo's regime in increasing transport infrastructure investment while improving the quality of governance in this republic. However, the expected outcomes are still not optimal, although the corruption perception index in Indonesia has improved in global rankings but is still not significant. Thus, an increase in the quantity and quality of investment in transport infrastructure as described by (Mohmand et al., 2017) through various funding partnership schemes has not shown encouraging results.

(Crain, \& Oakley, 1995) and (Henisz, 2002) argue that under conditions of poor governance quality, investment in transport infrastructure tends not to be the primary choice due to the large number of political interests and individual interests that intersect with the regime. In other words, the poor quality of governance will trigger corruption in the implementation of transportation infrastructure development. This will have an impact on the low economic returns from the transport infrastructure investment. The results of research conducted by (Crescenzi, Di Cataldo, \& RodríguezPose, 2016) supports this preposition where highway investment in some European countries with good governance quality is positively correlated with economic performance in those countries.

It can thus be concluded that the economic return of investment in transportation infrastructure depends on the credibility factor of governance including local governance and the effectiveness of the judicial system and the risk of corruption.

In Indonesia, many studies have examined the effect of infrastructure on the economy with varying outcomes. Research conducted by (Sibrani, 2002) found that infrastructure, in this case electricity and education, had a positive and significant impact on per capita income of Indonesian society, while road and telephone variables were not significant. Furthermore, (Yanuar, 2006) using 26 provincial panel data shows that physical capital, road infrastructure, telephone, health, and education have a positive effect on economic output. The results of the research from (Maryaningsih, Hermansyah, \& Savitri, 2014) concludes that road and electricity infrastructure conditions have a significant impact on per capita income growth, but this is not the case with ports. In addition, investment is proven empirically as a driving factor for Indonesia's economic growth.

This paper is intended to provide a conceptual review of the relationship between government quality and investment in transport infrastructure and its impact on Indonesia's economic growth qualitatively. Transport infrastructure investment is analyzed through road length 
INTERNATIONAL JOURNAL OF ACADEMIC RESEARCH IN BUSINESS AND SOCIAL SCIENCES Vol. 8, No. 7, July 2018, E-ISSN: 2222-6990 @ 2018 HRMARS

and port loading and unloading data; while the quality of government will be reviewed through the audit opinion from the Supreme Audit Board as the external auditor of the government against the performance report of the Ministry of Transportation during the period 2012-2016. Ministry of Transportation Republic of Indonesia is a carrier mandate in the management of development budget and development of transportation infrastructure in Indonesia. While economic growth is measured using data on the development of Gross Domestic Product (GDP) of Indonesia. This research is descriptive research by using non statistical analysis to analyze quantitative data that is by reading table, graph or number available then done description and interpretation.

\section{Transportation Infrastructure, Government and Economic Growth Transportation Infrastructure, Government Quality and Economic Growth}

The impact of a development activity on the regional economy can be measured through job creation, increased per capita income, growth and increased investment attractiveness, investment productivity, and various other benefits (Dixon, Parmenter, Powell, \& Wilcoxen, 1992). (Haryanto, 2012) explains that one of the deep discussions on infrastructure and economic relations emerged around the 1980s with the publication of a study conducted by (Aschauer, 1989) that analyzed the contribution of capital accumulation to the public sector to changes in productivity of the private sector in the United States. As stated by (Saragih, Ramadhana, Irawan, Hartomo, \& Irawan, 2010), the findings of the study indicate that basic infrastructure such as roads, airports, mass transit systems, drinking water and drainage have a significant effect on the productivity of the US economy. Other findings that point to the importance of infrastructure are further refined by (Canning, 1999), as disclosed in (Saragih et al., 2010), where in general the results of this study support what was discovered by (Aschauer, 1989) that infrastructure is statistically significant affect the output. These findings reinforce that Infrastructure can be a driver of economic growth, and on the contrary, economic growth itself can also be a pressure for infrastructure.

On the other hand, public sector organizations including government institutions have an important role in production activities. In real terms, the public sector can be incorporated into the production function because of the important role of the public sector as one input in production. The role of a productive public institution will create a potential positive relationship between government and growth (Barro, \& Martin, 1995). In his literature study on public spending, Barro began to incorporate some assumptions to explain the relationship between government and economic growth.

In theory, decision makers should base their decisions on strict cost-benefit considerations. However, research by (Short, \& Knopp, 2009) found that new transport investment decision-making in European countries "is generally politicized, rarely completely transparent, and few ex-post analyzes are concerned about whether the projects and policies implemented meet expectations.

\section{Relationship Analysis of Transportation Infrastructure and Economic Growth}

By 2016, Indonesia's per capita income has reached USD 3,601 or IDR 47.96 million per year, which puts Indonesia at the bottom of middle-income countries. The purpose of national development is to achieve prosperity and prosperity of the people equivalent to developed countries (high income). In order for Indonesia to be a high-income country, it certainly requires a higher growth than global growth. To reach a high-income country by 2030 , the national economy is required to grow on average between 6-8 percent per year. This is the main challenge of economic development. To be sustainable, such high growth must be inclusive, while maintaining economic 
INTERNATIONAL JOURNAL OF ACADEMIC RESEARCH IN BUSINESS AND SOCIAL SCIENCES Vol. 8, No. 7, July 2018, E-ISSN: 2222-6990 @ 2018 HRMARS

stability (Ministry of National Development Planning / National Development Planning Agency, 2015). One important indicator to know economic condition in a country in a certain period using data of Gross Domestic Product (GDP).

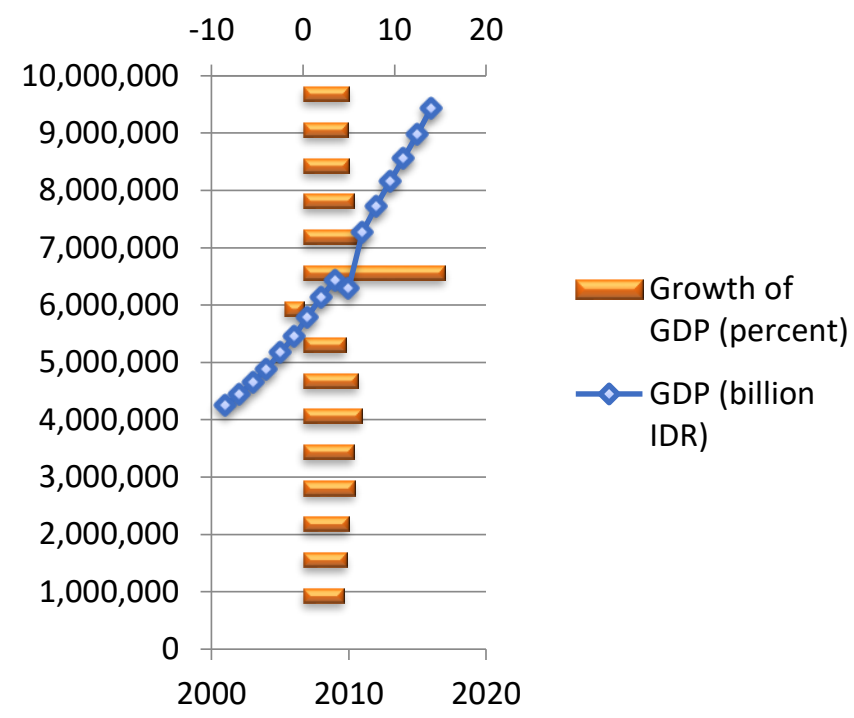

Fig 1. Indonesia GDP Data Year 2001-2016 (in IDR)

Overall GDP Indonesia tend to experience a positive trend that is always increasing from year to year during the year 2001-2009. In 2010, the GDP decreased from IDR 2,178,850 billion to IDR $2,134,459$ billion. There is a decline of 2.03 percent, caused by the imbalance of global economic recovery, causing considerable pressure on inflation and an effect on the decline of economic growth in Indonesia. The Indonesian government itself has targeted economic growth in 2018 of 5.4 percent. To achieve these targets, infrastructure must be encouraged in order to stimulate the business climate and not create barriers in the distribution of goods.

The Government of Indonesia has great attention to the infrastructure sector, including the transport infrastructure. Government policies such as infrastructure packages stipulated in various regulations and the increase in the fiscal stimulus budget in the infrastructure sector show the government's enormous attention to infrastructure development. The government's considerable attention to the infrastructure sector is appropriate given some of the studies' findings indicating the importance of infrastructure related to its impact on the economy. However, one of the main problems and challenges that will be faced in the period 2015-2019 is the availability of transportation infrastructure to support the improvement of economic progress is very limited and should be improved. The limited availability of transport infrastructure has been a major obstacle to exploiting opportunities for increased investment (Ministry of National Development Planning / National Development Planning Agency, 2015).

The procurement of transportation infrastructure and facilities includes huge investments, which can be provided by the state, private parties, foreign investments, or joint ventures. The problems faced by Indonesia as a developing country are limited funds available, budget allocation for infrastructure development is still limited to the condition of Indonesia's infrastructure is still lagging behind other countries. According to Global Competitiveness Report 2016-2017, Indonesia's infrastructure competitiveness ranking is ranked 60th out of 138 countries. While Thailand (49), Malaysia (24) and Singapore (2). Recognizing the weak infrastructure condition, infrastructure 
INTERNATIONAL JOURNAL OF ACADEMIC RESEARCH IN BUSINESS AND SOCIAL SCIENCES

Vol. 8, No. 7, July 2018, E-ISSN: 2222-6990 @ 2018 HRMARS

improvements are also an important concern in the National Development Planning Agency 20152019.

Road transport is the main mode of transportation that has the greatest contribution in the national economy, especially in connecting various economic and settlement centers, as well as sources of production, markets and consumers, thus benefiting primarily in improving population mobility and the distribution of various goods and services. In the broader context, the road network can also serve as a binding and unifying territory of the Unitary State of the Republic of Indonesia (NKRI) as a sovereign political entity (Bappenas, 2012). The following is a description of road developments in Indonesia during 2001-2015.

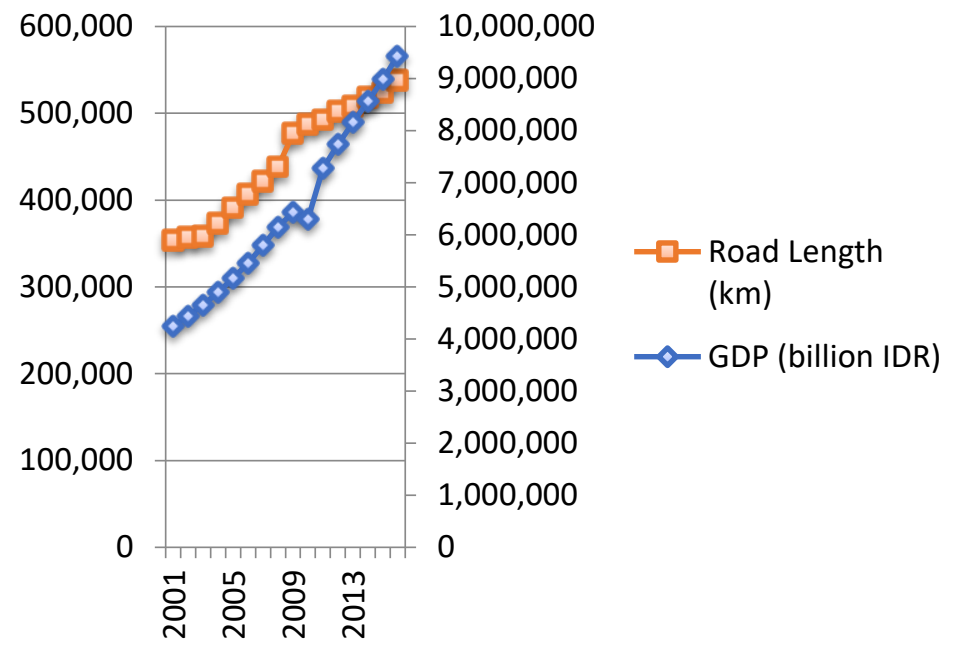

Fig 2. Comparison of GDP and Road Length in Indonesia (in IDR)

During 2001-2009 Indonesia's GDP has a direct relationship with the length of Indonesia's roads. Throughout the year, their relationship showed a positive trend. However, in 2010-2015 Indonesia's GDP shows a relationship that is inversely proportional to the length of roads in Indonesia. This shows that road investment in Indonesia for the last 5 years has not been able to boost economic growth directly. Increased economic growth that is not positively responded by road transport investment is caused by the low quality of human resources, as well as the continuous development of new roads in various districts and cities without maintenance of old roads, resulting in economic returns from new road investments is also accompanied by expenditure on high maintenance investment costs.

The problems faced by the current road sub-sector are the lack of road maintenance resulting in the declining quality and sustainability of land infrastructure services such as traffic congestion, high levels of accidents, environment and energy. In addition to infrastructure damage and slower growth of strategic road capacity, especially arterial and toll roads (about $70 \%$ of national, provincial and local road network systems are limited and functioning optimally) and no additional new roads or roads. All these issues must be addressed immediately to create better road sub-sector conditions (Bappenas, 2012).

These findings support research conducted by (Crescenzi et al., 2016) that results from a very weak relationship or no significant direct correlation between regional investments in either roads or other roads with economic growth. However, these findings are not in line with the results of research conducted by Agent and Moreno-Dodson in 2009 which explains that the road has a 
INTERNATIONAL JOURNAL OF ACADEMIC RESEARCH IN BUSINESS AND SOCIAL SCIENCES

Vol. 8, No. 7, July 2018, E-ISSN: 2222-6990 @ 2018 HRMARS

significant influence on economic growth in a region. This means that with the addition of long roads also increase the income of a country or region.

In addition to the special long-term road transport investment, marine transportation investment also contributes significantly to the economic development of Indonesia. A well-managed and efficient transportation transport system is a very important factor for an archipelagic country like Indonesia in enhancing economic competitiveness. Based on the 2016/2017 Global Competition Report, Indonesia's port infrastructure quality is ranked 75 out of 138 countries surveyed. This rating is similar to road quality, but is poor compared to the airport infrastructure quality rating (rank 62) and the quality of railway infrastructure (rank 39). The following is an overview of the development of shipping loading and unloading activities in Indonesian ports during 2002-2016.

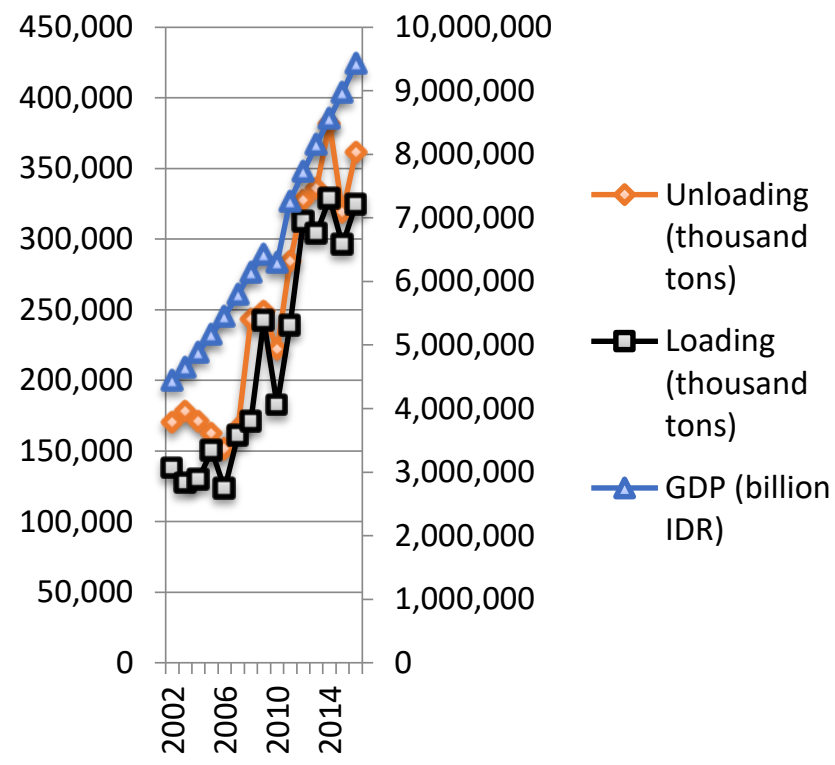

Fig 3. Comparison of GDP and Loading and Unloading Goods for Domestic Shipping in Indonesia (in IDR '000,000’)

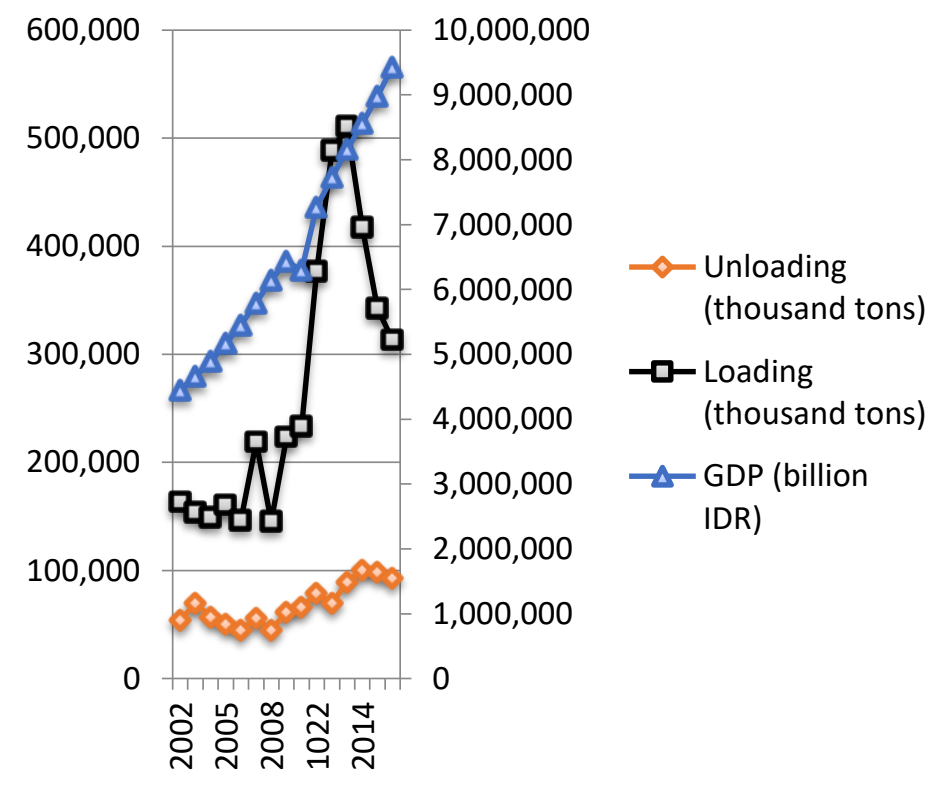


INTERNATIONAL JOURNAL OF ACADEMIC RESEARCH IN BUSINESS AND SOCIAL SCIENCES Vol. 8, No. 7, July 2018, E-ISSN: 2222-6990 @ 2018 HRMARS

Fig 4. Comparison of GDP and Loading and Unloading Goods for Overseas Shipping in Indonesia (in IDR '000,000')

Compared to 2015, the volume of loading and unloading of goods for domestic shipping increased in 2016 by 13.47 percent and 9.68 percent, respectively. In contrast, the volume of loading and unloading of goods on overseas shipping decreased by 5.67 percent and 8.60 percent, respectively. The simple picture above shows that the development of Indonesia's GDP has a relationship that is not in line with the development of loading and unloading of shipping goods domestically and abroad in the Indonesian port. Where the development of goods loading and unloading activities shows fluctuating data during the period 2002-2016. However, in 2010 Indonesia's GDP shows a direct relationship with the loading and unloading of goods in the country that has decreased (figure 3). This shows that marine transportation investment in Indonesia in general has not been able to encourage direct economic growth.

The problems and challenges of sea transportation currently consist of various sectors, namely the field of regulation, facilities and infrastructure and lack of good human resources in terms of quantity and quality. This is indicated by the role of the national shipping fleet, both domestic and overseas transport, is still very low. In addition, due to limited funds and lack of private investment, the existence of a single operator policy reduces competitiveness, resulting in a large subsidy to be borne by the government (Bappenas, 2012).

\section{The Relationship Among Government Quality, Infrastructure Investment and Economic Growth}

The development of sustainable transport infrastructure is a comprehensive effort of various dimensions of sector, region, involvement of actors, and substance. The issue of institutional preparedness is one of the central issues. In determining the amount of investment the transport infrastructure requires specific expertise in the planning, design, development, operation, maintenance, and evaluation of infrastructure and facilities for various modes of transport. There are three things that need to be highlighted in relation to institutional aspects, namely: (i) weaknesses in the implementation of laws and regulations, relating to the enforcement and in-consistency of laws and regulations, especially with regard to development licensing of various development activities (ii) weaknesses in the system (iii) weaknesses in the funding system related to the pattern of imposition of costs, processes and procedures on development financing, and the availability of funds that are far from adequate, especially for the development of transportation facilities and infrastructure (Ridwan, 2000). Therefore the role of government in making investment decisions must be based on a strict cost-benefit calculation. In this study, government quality can be analyzed through HR standards, legal discipline, financing and audit opinion by BPK.

(Ridwan, 2000) reveals that the development of globalization automatically triggers transportation infrastructure and means of reference to a global standard, where this global standard will require global standard human resources as well, and this requires the holding of standardized education, training and certification in all related areas. This is in line with the implementation of regional autonomy, where the improvement of the quality and quantity of human resources to support institutional empowerment at the central and regional levels should be improved. The autonomous regional government will have greater authority and responsibility in the future. Therefore the need for standardized education, training and certification systems should be applied to various areas of expertise related to the planning, implementation and maintenance of transport infrastructure and adapted to various levels of needs. Standard certification needs to be done so that 
INTERNATIONAL JOURNAL OF ACADEMIC RESEARCH IN BUSINESS AND SOCIAL SCIENCES Vol. 8, No. 7, July 2018, E-ISSN: 2222-6990 @ 2018 HRMARS

quality in various qualifications of workers has expertise with global and international standard quality.

In addition, the low level of discipline and enforcement level in related institutions could exacerbate the economic return of investment in transport infrastructure. This may be due to various reasons, such as inaccuracy of policies, incomplete regulations, lack of regulatory socialization, lack of strict law enforcement, no or less sanctions for violations. Weak governance quality will negatively impact the economic growth of a country.

Similarly, in terms of financing. The planned investment budget for transport infrastructure by the government will greatly affect economic returns. Based on the National Development Planning Agency (RPJMN) 2015-2019 that the government planned infrastructure projects for five years until 2019 cost up to Rp 5,500 trillion. In fact, the allocation of infrastructure spending in the state budget of revenues and expenditures (APBN) was recorded at Rp177.90 trillion at 20014, Rp 290.30 trillion in 2015, Rp317.10 trillion in 2016, Rp 387.30 trillion in 2017 and Rp 409.10 trillion by 2018. Assuming that per year the government is able to provide infrastructure spending of $\mathrm{Rp} 400$ trillion alone, the total for five years is only Rp 2,000 trillion. That is, the need for infrastructure costs of Rp 5,500 trillion is difficult to hold APBN only. Therefore, it is important for the government to involve the business world, because SOEs have limited capabilities, the pattern of cooperation between government and business entities (KPBU) or private public partnership (PPP) can be an unlimited financing solution. Because, with the role of the private sector, financing schemes can continue to grow.

If viewed based on the opinion of the Supreme Audit Board (BPK) RI against the Ministry of Transportation to see the quality of government in transport infrastructure investment, the data show since 2012-2016 Ministry of Transportation received unqualified opinion WTP from BPK RI for the fourth time in succession -raw. However, while accepting the WTP opinion does not mean the Ministry of Transport's financial report is free of errors. BPK still finds weaknesses of internal control system or non-compliance that needs to be improved. The weakness in the internal control system that concerns BPK is the revenue control system, especially on non-tax state revenue (PNBP) of Rp 5.84 billion in the Directorate General of Sea Transportation and the Directorate General of Civil Aviation. In addition, the asset control system in inventory management of Rp 10.37 billion in four working units in the first three echelon is not sufficient. Responding to BPK's recommendation, Kemenhub developed an Action Plan that was formulated as an effort to realize good governance and clean government, especially in the Ministry of Transportation (Bappenas, 2012).

Based on the opinion of BPK, it can be said that basically the quality of government in transportation infrastructure investment in Indonesia shows good performance, although still need improvement in some side. The rapid response shown by the Ministry of Transport affirmed the good quality of government in the government institutional system. Good government quality will affect the economic growth of a country towards the positive.

This finding is in line with (Crescenzi et al., 2016) which states that there is a strong and very significant relationship between secondary road investment and the quality of government. These findings suggest that, the positive rate of return of the investment infrastructure is mediated by the presence of adequate government institutions.

\section{Conclusion}

This paper has analyzed the relationship between government quality and investment in transport infrastructure and its impact on Indonesia's economic growth qualitatively. Although 
INTERNATIONAL JOURNAL OF ACADEMIC RESEARCH IN BUSINESS AND SOCIAL SCIENCES Vol. 8, No. 7, July 2018, E-ISSN: 2222-6990 @ 2018 HRMARS

infrastructure investment, particularly transportation, is a milestone for economic growth strategies in developed and developing countries, including Indonesia. However, the relationship between investment in transport infrastructure (proxied with road length and volume of loading and unloading of shipping goods) and economic growth, as a whole still shows an unclear relationship. This is reflected in the development of road length and GDP data showing unrelated relationships over the last 5 years; the development of loading and unloading activities of shipping goods both domestically and abroad in Indonesian ports and GDP shows only a direct relationship in 2010. These findings are supported by the $2016 / 2017$ Global Competition Report, where the quality of road infrastructure and the Indonesian port are both on ranking 75 . So generally speaking that investment in transportation infrastructure in Indonesia has not been able to encourage direct economic growth.

The results of the analysis found that mistakes in the allocation of funds to be one factor. Where the government tends to continue to develop new infrastructure without taking care of existing infrastructure. This problem is also revealed by the latest scientific literature, (Crescenzi et al., 2016) that investment in new infrastructure may take precedence over the maintenance of existing infrastructure. The Bappenas report shows the continued development of new roads in various districts and cities in Indonesia without maintenance of old roads resulting in low economic returns from the new road investment as coupled with high maintenance expenditure on investment costs. Furthermore, (Crescenzi et al., 2016) underscores the impact of transport infrastructure investment on economic growth is more limited than the operational costs of transport infrastructure investment itself, especially on access to human resource development and innovation.

Other findings, however, that the limited number of human resources in both quantity and quality in road management in almost all stakeholders, especially in making investment decisions, is also a factor causing investment in transportation infrastructure is responded negatively by economic growth, indicating that the quality of government plays an important role in determining the economic return of investment investment. The existence of differences in the credibility of government institutions is a constraint affecting the quality and quantity of transport investments managed by developed and developing countries (Mohmand et al., 2017); including local government governance and the effectiveness of the judicial system as well as the risk of corruption (Crescenzi et al., 2016).

Government quality analysis in this study is measured through HR standards, legal discipline, financing and audit opinion by BPK. The results show that the effectiveness of Indonesian government is only reflected from the BPK RI's opinion on the Ministry of Transportation's financial report showing good government quality because Kemenhub received Unqualified Exception (WTP) opinion for 4 consecutive years. However, these good performance results have not been supported by the achievement of HR standards, legal discipline and positive financing as well. These findings suggest that the relationship between government quality and investment in transport infrastructure to economic growth in Indonesia has not shown a positive relationship during the study period.

The final conclusion of this study provides the assumption that government institutions play an important role in the effectiveness of investment in transportation infrastructure, which ultimately affects the economic growth of a country. The results of (Crescenzi et al., 2016) also concluded the importance of government quality as a moderating variable. Good governance quality will provide a positive correlation between transportation investment and economic growth. Conversely, as stated by (Crain, \& Oakley, 1995) and (Henisz, 2000), the poor quality of governance will lead to corruption in the implementation of the development of transport infrastructure impacting low returns. 
INTERNATIONAL JOURNAL OF ACADEMIC RESEARCH IN BUSINESS AND SOCIAL SCIENCES

Vol. 8, No. 7, July 2018, E-ISSN: 2222-6990 @ 2018 HRMARS

Future studies are encourage to investigate the issue provided in the studies as well as examining the relationship among government quality, transportation infrastructure investment and economic growth both in Indonesia and regional levels. Thus, it can provide fruitful and fresh insights

\section{References}

Aschauer, D. A. (1989). Is Public Expenditure Productive?. Journal of Monetary Economics. 23, 177200.

Badan Pemeriksaan Keuangan RI. (2017). Ikhtisar HasilPemeriksaan Semester. https://www.bpk.go.id Badan Pusat Statistik. https://www.bps.go.id

Bappenas, K. N. P. P. N. (2012). Kajian Evaluasi Pembangunan Bidang Transportasi di Indonesia.

Barro, R. J. \& Martin, X. S. I. (1995). Economic Growth. New York, Mc GrawHill Inc.

Canning, D. (1999). Infrastructure's Contribution to Aggregate Output. World Bank Policy Research Working Paper No. 2246.

Competitiveness Global Report. https://www.weforum.org

Crain, M., \& Oakley, L. K. (1995). The Politics of Infrastructure. Journal of Law and Economics. 38, 117.

Crescenzi, R., Di Cataldo, M., \& Rodríguez-Pose, A. (2016). Government Quality and The Economic Returns of Transport Infrastructure Investment in European Regions. Journal of Regional Science, 56(4), 555-582. https://doi.org/10.1111/jors.12264

Dixon, P.B., Parmenter, B. R., Powell, A. A., \& Wilcoxen, P. J. (1992). Notes and Problems in Applied General Equilibrium Economics. North-Holland, Amsterdam.

Haryanto, I. (2012). Dampak Investasi Infrastruktur Transportasi terhadap Penyerapan Tenaga Kerja Sektor Ekonomi dan Distribusi Pendapatan Masyarakat di Provinsi Jawa Barat. Disertasi. Program Pascasarjana Institut Pertanian Bogor, Bogor.

Henisz, W. J. (2002). The Institutional Environment for Infrastructure Investment. Industrial and Corporate Change. 11, 355-389.

Maryaningsih, N., Hermansyah, O., \& Savitri, M. (2014). Pengaruh Infrastruktur terhadap Pertumbuhan Ekonoml Indonesia. Buletin Ekonomi Moneter dan Perbankan, 17(1), 62-98. https://doi.org/10.21098/bemp.v17i1.44

Ministry of National Development Planning / National Development Planning Agency. (2015). National Medium Term Development Plan 2015-2019, 313. https://doi.org/10.1017/CB09781107415324.004

Mohmand, Y. T., Wang, A., \& Saeed, A. (2017). The Impact of Transportation Infrastructure on Economic Growth: Empirical Evidence from Pakistan. Transportation Letters, 9(2), 63-69. https://doi.org/10.1080/19427867.2016.1165463

Ridwan, A. S. (2000). Tantangan dan Pemecahan Masalah Sektor Transportasi di Indonesia: Sumbangan Pemikiran ITB 1, 32(2), 89-123.

Sahoo, P., Dash, R. K., \& Nataraj, G. (2012). China's Growth Story: The Role of Physical and Social Infrastructure. Journal of Economic Development, 37(1), 53-75.

Saragih, F. R., Ramadhana, F. H., Irawan, F., Hartono, D., \& Irawan, T. (2010). Pengaruh Pelaksanaan Proyek Infrastruktur terhadap Perkembangan Variabel Makro. Pusat Pengolahan Resiko Fiskal, Departemen Keuangan RI. Jakarta.

Short, J., \& Knopp, A. (2005). Transport Infrastructure: Investment and Planning, Policy and Research Aspects, Transport Policy. 124, 360-367. 
INTERNATIONAL JOURNAL OF ACADEMIC RESEARCH IN BUSINESS AND SOCIAL SCIENCES

Vol. 8, No. 7, July 2018, E-ISSN: 2222-6990 @ 2018 HRMARS

Sibrani, M. H. M. (2002). Kontribusi Infrastruktur terhadap Pertumbuhan Ekonomi Indonesia. Tesis Program Pascasarjana Universitas Indonesia, Jakarta.

Yu, N., De Jong, M., Storm, S., \& Mi, J. (2012). The Growth Impact of Transport Infrastructure Investment: A Regional Analysis for China (1978-2008). Policy and Society, 31(1), 25-38. https://doi.org/10.1016/j.polsoc.2012.01.004

Yanuar, R. (2006). Kaitan Pembangunan Infrastruktur dan Pertumbuhan Output serta Dampaknya terhadap Kesenjangan di Indonesia. Tesis. Institut Pertanian Bogor. Bogor. 